Nig. J. Biotech. Vol. 38 (1) : 48-54 (June 2021)

ISSN: 01891731

Available online at

http://www.ajol.info/index.php/njb/index

and www.biotechsocietynigeria.org

DOI: https://dx.doi.org/10.4314/njb.v38i1.5

\title{
Comparative Study on the Natural and Synthetic Hormones of Clarias gariepinus Broodstock
}

\author{
*Onyia, L.U1. Ali, H. D ${ }^{1}$, Bello, H.A2 ${ }^{2}$, Onyia, E.C ${ }^{3}$. and Musa, M $^{4}$ \\ ${ }^{1}$ Department of Fisheries, ${ }^{3}$ Department of Zoology, Modibbo Adama University of Technology \\ PMB 2076, Yola Adamawa State. \\ 2Department of Biology, Federal College of Education, Yola, Adamawa State. \\ ${ }^{4}$ Department of Fisheries Technology, College of Agriculture Ganye, Adamawa State
}

\begin{abstract}
The study was carried out for six (6) weeks at the Department of Fisheries Teaching and Research farm, Modibbo Adama University, Yola, to compare the reproductive performance of Clarias gariepinus using synthetic (ovaprim) and natural (C. gariepinus pituitary extract) hormones . At the end of the feeding trial, the fecundity, percentage fertilization, hatchability, and survival rates of the hatchlings were estimated using standard procedure. The hatchlings were further raised for six weeks and the increase in weight was determined. The results showed that female broodstock injected with $C$. gariepinus pituitary extract (CgPE) had a higher fecundity $(124,000)$ while the female injected with Ovaprim had 65,000 eggs. The weight of the testes significantly differed $(p<0.05)$ across the treatments, the right lobe weighed $1.63 \mathrm{~g}$ while the left lobe weighed $1.98 \mathrm{~g}$ . Subsequently, a higher fertilization rate was recorded in CgPE (91.1\%) while Ovaprim had $85.55 \%$. However, Ovaprim had a higher percentage hatchability of $82.93 \%$ while CgPE had $82.73 \%$. At the end of the six (6) weeks feeding period, the survival rate was higher in the fish treated with CgPE $(82.31 \%)$ while the fish injected with Ovaprim had $79.68 \%$. The research exposed the efficacy of using CgPE in the absence of synthetic hormone, CgPE is a preferred substitute that Hatchery managers can utilize for fingerlings production.
\end{abstract}

Keywords: Natural, Synthetic, Hormones, Breeding performance, Clarias gariepinus *Correspondence author: uchelucky@mautech.edu.ng, Phone +2348058047800.

\section{Introduction}

The study of Onyia et al. (2015) reported that fish is an essential source of animal protein because of the nutrients it contains and more efficient in terms of reproduction. With the rate at which the world population increases, the demand for fish has increased, it is a cheap source of protein (Idris et al., 2018). African catfish is the most cultivated aquatic organism in Nigeria, it is acceptable and consumed by the majority of the population, it is bred all year round, and the flesh quality is high (Ochokwu et al., 2015a). C. gariepinus can be cultured all year round. In Nigeria, aquaculture has progressed steadily and the use of certain culture media such as concrete, fiber, and tarpaulin for fish rearing have been employed (Saidu et al., 2021). Recently, aquaculture has been practiced, it has successfully gained attention (Ochokwu et al., 2016), it is a supplement and an alternative for the poor catch from the wild. Aquaculture can only be successful if there are viable sperm and gravid eggs, subsequently the quality and quantity of fish larvae and fingerlings available for ongrowing market size (Ochokwu et al., 2015a). The reproduction technique is one of the factors that affect the breeding performance of any fish species on the farm (Ochokwu et al., 2015a). It influences the rate of fertility and hatchability during the hatching process. The breeding process can be carried out naturally or through artificial hypophysation. This is the use of hormones either natural or synthetic. Induced breeding through hypophysation has produced a high percentage of fertilization and increased 
the hatchability of the eggs, higher growth and survival, and adaptability of the larvae against environmental change (Oleh \& Olena, 2016).

Moreover, most of the used synthetic hormones are of high cost such as the human Chorionic Gonadotropin (HCG) (Olaniyi \& Akinbola, 2013); Common carp pituitary extract is not available at all time hence the accessibility by the fish farmers are limited (Olaniyi \& Akinbola, 2013; Saidu et al., 2021). Meanwhile, ovaprim which is the most commonly used is effective but costly. Hill et al. (2009) previously reported an ovulation increase of $50 \%$, spermatic $54 \%$, and minimal mortality after inducing with Ovaprim. However, authors have reported success in the use of ovaprim such as (Hill et al., 2009) used it on Cyprinidae and Characidae, and Cobit idae species by (Yanong et al., 2009). Presently the increase in the exchange rate has led to an increase in the price of ovaprim, this has given rise to the source of an alternative that will give the same quality and output, value, and latency period. Saidu et al. (2021); Adebayo \& Popoola (2008) conveyed that the non-synthetic hormone from $C$. gariepinus is a cost-effective and available alternative for hypophysation and can be prepared in a suspension.

The major limitation in aquaculture sustainability is the accessibility of matured gravid fish with high fecundity, males of proven quality with high sperm volume, viable and motile (Ochokwu et al. 2019), as well increase in weight gain, and high survival (Ochokwu et al., 2020; Onyia et al., 2015). However, understanding the appropriate techniques and cost-effective hormones for hypophysation would promote aquaculture development and wax commercial fish culture. The study examined the response of the broodstock on the hormone treatment and its result on the egg and sperm quality of the African mud Catfish (Clarias gariepinus). To determine its impact on the weight gain and length of the hatchlings as well as the survival of fingerlings.

\section{Materials and Method}

\section{Study area}

The research took place in the Hatchery complex of the Modibbo Adama University of Yola, Nigeria, It has a latitude of $9.20-9.33^{\circ} \mathrm{N}$, longitude $12.30-12.50^{\circ} \mathrm{E}$, and an altitude of $185.9 \mathrm{~m}$, with an annual rainfall of $759 \mathrm{~mm}$, a maximum temperature of $39.7^{\circ} \mathrm{C}$. (Ochokwu et al., 2015b).

\section{Source of broodstock}

Parent C. gariepinus was collected from the earthen pond in the Department.

\section{Extraction and preparation of pituitary extract}

Four male fishes were sacrificed for the research; the head region was cut vertically down, the knife was used to remove the lower part of the fish. The brain compartment was exposed and the pituitary gland was collected using a sterilized needle. The pituitary gland was ground in a mortar and saline solution was added.

\section{Induce breeding}

The selected broodstocks was weighed to estimate the volume of the ovaprim and pituitary extract to be injected; three of the female broodstocks were injected with Ovaprim while the other three were given pituitary extract based on their body weight, while the male received half of the dose that was given to a female. The latency period lasted for ten hours. The eggs were stripped into a dry clean bowl by adding a little pressure on the abdomen. The milt was collected by incising the abdomen of the male using a surgical blade, the gonad was located toward the urogenital papillae, the gonad was removed and cleaned with clean material to avoid contamination with blood, was incised and the milt was collected in a clean and dry bowl. The relative fecundity (RF) and stripping percentage (SP) were calculated according to Onyia et al., (2015) and Tiamiyu et al., (2015).

Relative Fecundity $=$ Number of stripped eggs/Bodyweight x100

Stripping percentage $=$ Weight of stripped eggs/ Bodyweight x 100

\section{Fertilization and incubation}

The milt collected was mixed with the eggs and a little quantity of saline water was added to enhance fertilization, the fertilized eggs were stirred for 5 minutes before incubating on the kakaban (Onyia et al., 2020).

$$
\begin{aligned}
& \text { Percentage fertilization = } \\
& \frac{\text { total eggs -unfertilized eggs }}{\text { total eggs }} \times 100 \\
& \text { Percentage hatchability = } \\
& \frac{\text { number of hatchlings }}{\text { number of eggs incubateed }} \times 100 \\
& \text { Percentage survival }=\frac{\text { final number of fish }}{\text { initial number of fish }} \times 100 \\
& \text { (Onyia et al., 2010) }
\end{aligned}
$$


Growth Performance Monitoring

Before stocking the hatchlings in the experimental bowls, the weight and length of the hatchlings were taken as initial weight. A $30 \mathrm{~cm}$ measuring ruler was used for taking the length and a sensitive scale for the weight. This was done weekly.

The experimental setup was made up of a completely randomized design (CRD), it consists of two treatments and three replicates each resulting in six units.

\section{Statistical analysis}

The data collected from the experiment were subjected to one-way analysis of variance (ANOVA) using SPSS 2020 and means separation was done using LSD.

\section{Results}

The results of the $C$. gariepinus treated with Ovaprim and C. gariepinus Pituitary Extract $(\mathrm{CgPE})$ are shown in Table 1, which showed the Weight of the breeders across the treatments. The broodstock injected with Ovaprim weighed (2.8kg for male and $1.6 \mathrm{~kg}$ for females). and for the Pituitary Extract $(1.9 \mathrm{~kg}$ for male and $1.0 \mathrm{~kg}$ for females) respectively. The weight of the right and left lobes of the testes injected with AgPE were (1.98g and $1.63 \mathrm{~g}$ ) while synthetic hormones were $(2.8 \mathrm{~g}$ and $1.6 \mathrm{~g}$ respectively). The total number of eggs showed a similar pattern, while the mean egg weight was higher in C. gariepinus injected with CgPE (200g) and those injected with Ovaprim weighed $(106 \mathrm{~g})$. The relative fecundity across the treatments was higher in the breeders injected with CgPE $(124,000)$ followed by broodstock injected with Ovaprim $(65,000)$. The hatchability was $(82.93 \%)$ in the female treated with Ovaprim and $(82.78 \%)$ in $\mathrm{CgPE}$. However, the survival rate was higher in CgPE treated females $(82.31 \%)$ and lowest in Ovaprim treated females $(79.68 \%)$ after a week. The hatching and latency period were 48hours and 10hours and five minutes respectively for each of the treatments at a temperature of $31^{\circ} \mathrm{C}$ to $32^{\circ} \mathrm{C}$.

The increase in fish length (Table 2), showed that the broodstock injected with CgPE had a better growth in weeks 2, 4, 5, and 6 $(10.03 \pm 0.14,23.00 \pm 0.17,31.67 \pm 0.14$, and $37.67 \pm 0.14)$. The Ovaprim had a higher growth performance in the third week $(18.83 \pm 0.12)$.

The increase in weight (Table 3 ) showed that the hatchlings from synthetic hormones were higher in weeks 3, 5, and 6 while CgPE were better than those from synthetic hormones in weeks 2 and 4. However, there was no significant difference in the relative growth rate (142) and specific growth rate (1.42) across the treatments table 4 . The water quality parameters observed were temperature 31 $32^{\circ} \mathrm{C}$, dissolved oxygen 4.26 , and $\mathrm{pH} 6.5$

Table 1: The Fecundity, testis weight, length, fertilization, hatchability, and survival of $C$. gariepinus induced with ovaprim and CgPE

\begin{tabular}{lll}
\hline Parameters & Ovaprim & Pituitary extract \\
\hline Weight of male Broodstock $(\mathrm{kg})$ & $2.8^{\mathrm{a}}$ & $1.9^{\mathrm{b}}$ \\
Weight of female Broodstock $(\mathrm{kg})$ & $1.6^{\mathrm{a}}$ & $1.0^{\mathrm{b}}$ \\
Weight of Testis (Right lobe)/g & $1.8^{\mathrm{a}}$ & $1.63^{\mathrm{b}}$ \\
Weight of Testis (Left lobe)/g & $1.75^{\mathrm{b}}$ & $1.98^{\mathrm{a}}$ \\
Weight of eggs $(\mathrm{g})$ & $106^{\mathrm{b}}$ & $200^{\mathrm{a}}$ \\
Number of eggs per $1 \mathrm{~g}$ & $615^{\mathrm{b}}$ & $620^{\mathrm{a}}$ \\
Absolute Fecundity & $65,000^{\mathrm{b}}$ & $124,000^{\mathrm{a}}$ \\
Relative Fecundity & $23.21^{\mathrm{b}}$ & $65.3^{\mathrm{a}}$ \\
$\%$ Fertilization & $85.55^{\mathrm{b}}$ & $91.1^{\mathrm{a}}$ \\
$\%$ Hatchability & $82.93^{\mathrm{a}}$ & $82.78^{\mathrm{a}}$ \\
$\%$ Survival for a week & $79.68^{\mathrm{b}}$ & $82.31^{\mathrm{a}}$ \\
\hline
\end{tabular}

Means with different superscript are significantly different $(p<0.05)$ 
Table 2: The increase in length $(\mathrm{mm})$ of hatchlings produced using Ovaprim and Pituitary gland extract

\begin{tabular}{lll}
\hline Weeks/Treatments & Ovaprim & Pituitary Extract \\
\hline 1 & $7.33 \pm 0.0^{\mathrm{b}}$ & $7.66 \pm 0.88^{\mathrm{a}}$ \\
2 & $8.67 \pm 0.1^{\mathrm{b}}$ & $10.3 \pm 0.14^{\mathrm{a}}$ \\
3 & $18.83 \pm 0.12^{\mathrm{a}}$ & $16.33 \pm 0.08^{\mathrm{b}}$ \\
4 & $22.33 \pm 0.76^{\mathrm{a}}$ & $23.00 \pm 0.17^{\mathrm{b}}$ \\
5 & $28.67 \pm 0.088^{\mathrm{b}}$ & $31.67 \pm 0.14^{\mathrm{a}}$ \\
6 & $36.67 \pm 0.202^{\mathrm{a}}$ & $37.33 \pm 0.14^{\mathrm{b}}$ \\
\hline
\end{tabular}

Mean on a row with different superscript are significantly different $(p<0.5)$

Table 3: The increase in weight $(\mathrm{mg})$ of hatchlings produced with Ovaprim and pituitary gland extract.

\begin{tabular}{lll}
\hline Weeks/Treatments & Ovaprim & Pituitary Extract \\
\hline 1 & $0.060 \pm 0.0^{\mathrm{a}}$ & $0.633 \pm 0 .^{\mathrm{b}}$ \\
2 & $1.333 \pm 0.0^{\mathrm{b}}$ & $2.100 \pm 0.0^{\mathrm{a}}$ \\
3 & $3.167 \pm 0.03^{\mathrm{b}}$ & $2.733 \pm 0.088^{\mathrm{a}}$ \\
4 & $3.090 \pm 0.05^{\mathrm{a}}$ & $4.03 \pm 0.04^{\mathrm{b}}$ \\
5 & $6.066 \pm 0.04^{\mathrm{a}}$ & $5.867 \pm 0.040^{\mathrm{b}}$ \\
6 & $7.467 \pm 0.03^{\mathrm{b}}$ & $7.067 \pm 0.055^{\mathrm{a}}$ \\
\hline
\end{tabular}

Means on a row with different superscript are significantly different $(p<0.05)$

Table 4: Growth parameters of $C$. gariepinus induced with ovaprim and pituitary gland

\begin{tabular}{lll}
\hline Parameters & Ovaprim & Pituitary extract \\
\hline Final weight & $36.67^{\mathrm{b}}$ & $37.33^{\mathrm{a}}$ \\
Initial weight & 7.33 & 7.66 \\
Weight gain & 29.34 & 29.67 \\
Final length & 7.467 & 7.067 \\
Initial length & 0.060 & 0.633 \\
Length gain & $7.407^{\mathrm{a}}$ & $6.434^{\mathrm{b}}$ \\
Specific growth rate & 1.42 & 1.42 \\
Relative growth rate & 142 & 142 \\
Condition factor & $8.81^{\mathrm{b}}$ & $10.58^{\mathrm{a}}$ \\
\% Survival & 64 & 68 \\
\hline
\end{tabular}

Means on a row with different superscript are significantly different $(p<0.05)$

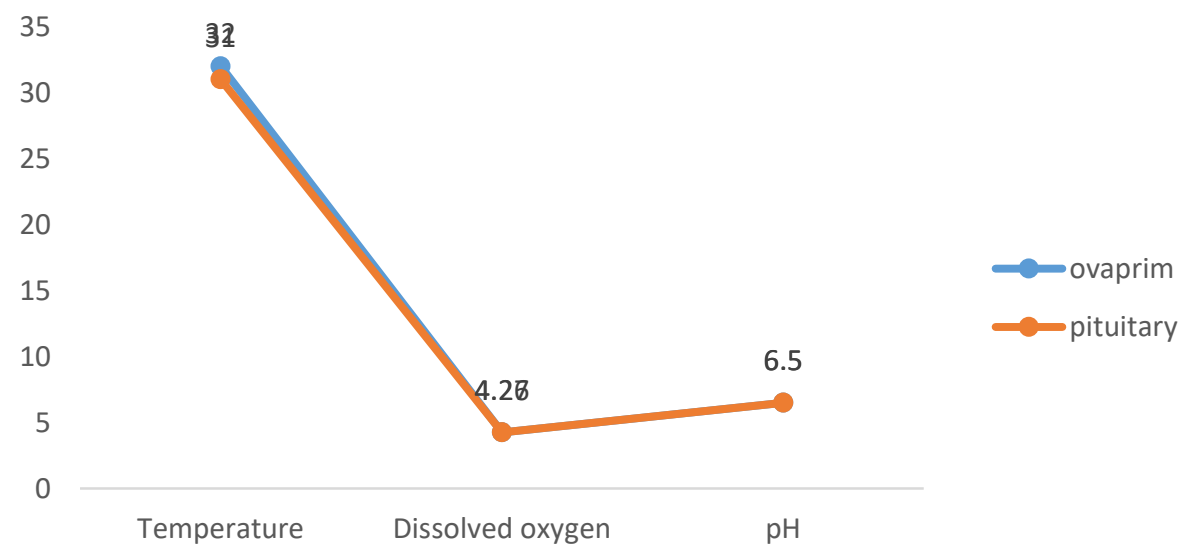


Figure 1: Water quality parameter during the rearing period

\section{Discussion}

The study compared the ovaprim and pituitary extract from C. gariepinus, its impact on the fecundity, weight of the testes, fertility, hatchability, and growth of the hatchlings. The result acquired from the research showed the significance of induced breeding using synthetic and natural hormones. It showcased its importance to aquaculture sustainability. The weight in $\mathrm{kg}$ of the males ranged from 1.9 to $2.8 \mathrm{~kg}$ and females from 1.0 to $1.6 \mathrm{~kg}$ respectively. Although both broodstocks treated with the hormones responded positively there was however a significant difference in the result obtained.

Fecundity in fish is expressed as the quantity of gamete that is produced within a breeding time (Hizons et al., 2014). The fecundity obtained in this study was higher in the female treated with pituitary gland extract; this could be as a result of the high weight of the donor fish (Olaniyi and Akinbola, 2013). However, Mule and Saver (2017) stated various factors such as hormonal influence, environmental variation, spawning frequency and, food availability as the source of high or low fecundity in fish. Meanwhile, other factors include water current, light, $\mathrm{pH}$, temperature, and the degree of rainfall. The pituitary extract gave a higher percentage of fertilization in this study, this was not in agreement with the report of (Chattopadhyay, 2018) who reported a low fertilization rate in $C$. gariepinus induced with pituitary extract. However, there was no significant difference in the percentage of Hatchability of both $C$. gariepinus treated with both hormones. This agreed with (Hossain et al. 2012) who worked on C. gariepinus fish induced with synthetic and natural hormone. The broodstock induced with pituitary gland had higher survival (82.31\%) after six weeks compared to the broodstock induced with ovaprim $(79.68 \%)$, this agreed with (Chattopadhyay, 2018)

The growth of the larvae monitored for six weeks revealed a significant difference $(P<0.05)$ among the treatments at the early stage, meanwhile, there was no significant difference in the SGR and RGR, this agreed with (Abdul et al., 2017) who recorded a similar growth rate after the feeding trial for 28 days, the same trend was reported by Ndimele and Owodeinde (2012). However, Ikechukwu et al. (2019) explained that the growth among the fishes treated with ovaprim and pituitary gland extract was not significantly different. The result exposed that there is no difference in the use of ovaprim and pituitary extract, this exposed that each can supplement for the other. Although when considering the cost one can state that the use of pituitary is more effective than ovaprim. In this research the increase in growth was poor this could be attributed to the bowls used and genetic makeup of the parent as previously reported by Ochokwu et al., (2019), also the nutrient composition of the feed that the fish ate, $\mathrm{pH}$, and oxygen content of the water. These factors affect the growth of the hatchlings.

\section{Conclusion}

The study explained the efficacy of using the pituitary gland from the catfish which is accessible and cost-effective for induced breeding and rearing of larvae which in turn will lead to the availability of fingerlings all year round, subsequently assures sustainability of aquaculture. Both the ovaprim and Pituitary extract from $C$. gariepinus positively influenced the latency period, fecundity, and testes quality of the fish, it exerted positive change in fertility, hatchability growth in weight, length, and survival of the hatchlings. Finally, fish farmers are advised to use the natural hormone for inducing catfish breeding.

\section{References}

Abdul R.B., Edward K., Sogbesan O.A., (2017), Comparative Studies on Clarias gariepinus Pituitary Extracts and Synthetic Hormone on Induced Spawning and Growth Performance of the African Catfish Clarias gariepinus Fry, Dairy and Vet. Sci. J., 4(3):555638, https://doi.org/10.19080/JDVS.2017.04.55563 $\underline{8}$

Adebayo O.T and Popoola, O.M (2008) Comparative evaluation and efficacy and cost of Synthetic and non-synthetic hormones for artificial breeding of African catfish (Clarias gariepinus). J. Fish. Aquat. Sci., 3:66-71, DOI: $10.3923 / \mathrm{jfas} .2008 .66 .71$. 
Chattopadhyay, N.R.R. (2018). Comparative efficacy of carp pituitary extract and Ovaprim during captive breeding of Cat Fish, Pabda (Ompok pabda). J. Agric. Sci. Bot., 2 (1):25-36, DOI: $10.35841 / 2591-7897.2 .1 .25-36$.

Hill, J.E., Kilgore, K.H., Pouder, D.B., Powell, J.F.F., Watson, C.A and Yanong, R.P.E (2009) Survey of Ovaprim use as a spawning aid in ornamental fishes in the United States as administered through the University of Florida Tropical Aquaculture Laboratory (2005- 2007). North American Journal of Aquaculture, 71(3):206-209. DOI:10.1577/A08-020.1

Hizon, M.A., Johnson, D.W and Sogard, S.M. (2014). Boffffs (On the Important of Conserving Structure in Fishery Population) ICES Journal of Marine Science, 71(8):2171-2185, oi:10.1093/icesjms/fst200

Hossain, M.B. Rahman, M.M. Sarwer, M.G. Ali, M.Y. Ahamed, F. Rahman, S. Fulanda, B. Rahman, M.M. Subba, B.R. and Hossain, M.Y. (2012). Comparative Study of Carp Pituitary Gland (PG) Extract and Synthetic Hormone Ovaprim Used in the Induced Breeding of Stinging Catfish, Heteropneustes fossilis (Siluriformes: Heteropneustidae). Our Nature 10:89-95.

Idris, S., Ochokwu, I. J., and Dambatta, M. A. (2018). Fish Consumption Preference among Residents of Hadejia Metropolis, Jigawa State, Nigeria. International Journal of Fisheries and Aquaculture Research 4(2):36-41

Ikechukwu, C. C., Nsofor, C. I., Ikeogu, C. F. and 1ogbonnaya, H. F. (2019). Comparative Effects of Ovaprim and Pituitary Hormone on The Inducement, Hatchability, Survival and Growth Performance of Clarias gariepinus. Journal of Aquatic Sciences, 34 (2): 125 - 131 (2019) DOI:

https://dx.doi.org/10.4314.jas.v34i2.15

Mule, A.B and Sarver, N.S. (2017). Role of Different Factors on Reproduction of Fish. International Journal for Innovative Research in Multidisciplinary Field, 7(3): 86-93

Ndimele, P.E., and Owodeinde, F.G. (2012). Comparative Reproductive and Growth Performance of Clarias gariepinus (Burchell, 1822) and Its Hybrid Induced with Synthetic Hormone and Pituitary Gland of Clarias gariepinus. Turk. J. Fish. Aquat. Sci. 12: 619626. DOI: $10.4194 / 1303-2712-v 12$ _3_09
Ochokwu, I. J., Apollos, T. G and Oshoke, J. O (2015a). Effect of Egg and Sperm Quality in Successful Fish Breeding. IOSR Journal of Agriculture and Veterinary Science, 8(8): 48-57, DOI: $10.9790 / 2380-08824857$

Ochokwu, I. J., Dasuki, A. Oshoke, J.O, (2015b). Azanza Garckeana (Goron Tula) As an Edible Indigenous Fruit in North Eastern Part of Nigeria. Journal of Biology, Agriculture and Healthcare, 5 (15) 26-32.

Ochokwu, I.J., Bichi, A.H and Onyia, L.U. (2016). Intra-specific Hybridization between Two Strains of Clarias gariepinus from South West and North Western Nigeria. Nigerian Journal of Fisheries and Aquaculture 4(1): 34 41.

Ochokwu, I. J., Nwabunike, M. O. and Udeh, G. N. (2019). Evaluation of Milt Quality oF Clarias anguillaris (Linnaeus, 1758) Broodstock Fed Varying Inclusion Levels of Wild Hibiscus Azanza garckeana Pulp Meal. Journal of Aquatic Sciences, 34 (1): 23-31 (2019) DOI: https://dx.doi.org/10.4314.jas.v34i1.4.

Ochokwu, I.J., Umaru, J and Saidu, K.A. (2020). Growth and Nutrients Utilization of Clarias gariepinus Fingerlings (Burchell, 1822) Fed Telfairia Occidentalis Leaf Meal as Feed Additive. International Journal of Fisheries and Aquaculture Research, 6(2): 1-12

Olaniyi, C.O., Akinbola, D.O. (2013) Comparative Studies on The Hatchability, Performance and Survival Rate of African Catfish (Clarias gariepinus) Larval Produced: Using Ovaprim and Catfish Pituitary Extract Hormones. Journal of Biology, Agriculture and Healthcare 3: 11-16.

Oleh, M. and Olena, F. (2016). Ways of optimization of breeding conditions of fish by using artificial spawning grounds. World Scientific News 49(1): 1-58

Onyia, L. U., Ochokwu, I. J., Diyaware, M.Y. and Michael, K. G. (2015). Effects of Azanza garckeana on egg quality of African catfish (Clarias gariepinus) (Burchell, 1822)

Broodstock. Int. J. Fish. Aquat. Sci., 4(2): 3539. http://dx.doi.org/10.19026/ijfas.4.2204

Onyia, L.U., B.M.B. Ladu and S.O. Olufeagba (2010). Evaluation of Hatchability, survival and Growth rates in reciprocal crosses of three strains of Clarias anguillaris under controlled 
Hatchery. World Journal of Biotechnology. 11 (1):1719-1724.

Onyia, L.U., Ochokwu, I.J and Robinson, V. (2020). Intraspecific hybridization of Normal Pigmented and Albino Clarias gariepinus from Yola and Katsina under Hatcher Condition. Nig. J. Biotech. 37(2): 152-156. DOI:

https://dx.doi.org/10.4314/njb.v37i2.15.

Saidu, K.A., Paul, M.M., Ochokwu, I.J and Bichi, A.H. (2021). Influence of ovaprim and Pituitary Gland on the Reproductive Indices and Growth of Clarias gariepinus (Burchell, 1822) Broodstock Reared in an indoor and Outdoor Pond. Int. J. Aquacult., 11(1): 1-12, DOI: 10.5376/ija.2021.11.0001.

Tiamiyu L.O., Okomoda V.T., and Izundu C.I., 2015, Nutritional value of Hydrothermally processed Citrullus lanatus Seeds in the Diet of Clarias gariepinus, Int. J. Aquacult., 5(10):14, doi: 10.5376/ija.2015.05.0010

Yanong, R.P.E., Carlos, M., Craig, A.W. (2009) Use of Ovaprim in Ornamental Fish

Aquaculture. Program in fisheries and Aquatic Sciences, Institute of Food and Agricultural Sciences. University of Florida. FA161pp. 